\title{
KAJIAN PENGELUARAN DAN PEMUATAN KAYU DENGAN ALAT EXPO-2000 YANG DISEMPURNAKAN
}

\section{(Study on Logs Extraction and Loading Using Improved Expo-2000)}

\author{
Oleh/By : \\ Wesman Endom ${ }^{1)}$, Sukanda ${ }^{1)}$, Yayan Sugilar ${ }^{2)} \&$ Hasan Basri $^{2)}$
}

\begin{abstract}
As an attempt to overcome difficulty in manual collection of wood logs from felling of particular forest stands located on steep or inclined area, it is necessary to find out a breakthrough by providing extraction equipment which should be inexpensive, easily operable, productive, and low in operation as well as maintenance cost. As the relevance, trial on collecting and loading/ unloading of wood logs using the improved Expo-2000 equipment was carried out at Sub Forestry District of Ciguha, administratively under Forestry District of Sukabumi (West Java).

The Expo-2000, following its improvement that incorporated the use of endless cables, afforded the satisfactory productivity in wood gathering at $5 \mathrm{~m}^{3} . \mathrm{hm} /$ hour with loading/ unloading performance of about 50 $m^{3} . m /$ hour. As such the investment cost was $\mathrm{R} p 100$ millions, so the total ownership and operation cost amounted to Rp 60,175 per hour. Therefore, the expenses of wood collecting was Rp12,305 per $\mathrm{m}^{3}$. hm, and wood loading cost was $\mathrm{Rp} 1,135 \mathrm{per} \mathrm{m}^{3} . \mathrm{m}$. These expenses were quite effective and efficient compared to those implementing the conventional system, which incurred the corresponding cost i.e. Rp 35,000 and Rp 15,000 respectively.
\end{abstract}

Keyword: Logs extraction, effective, efficient, Expo-2000.

\begin{abstract}
ABSTRAK
Dalam upaya mengatasi kesulitan mengumpulkan kayu-kayu hasil tebangan di daerah curam dengan cara manual, diperlukan terobosan berupa penyediaan alat ekstraksi kayu yang tidak mahal, mudah dioperasikan, produktif dengan biaya operasi dan perawatan rendah. Sesuai dengan harapan itu dilakukan kegiatan penelitian uji coba pengumpulan kayu dan muat bongkar dengan menggunakan hasil rekayasa alat Expo-2000 di daerah hutan Resort Polisi Hutan (RPH) Ciguha, Kesatuan Pemangkuan Hutan (KPH) Sukabumi, Jawa Barat.
\end{abstract}

\footnotetext{
${ }^{1)}$ Peneliti pada Pusat Penelitian dan Pengembangan Hasil Hutan, Bogor

2) Teknisi Litkayasa pada Pusat Penelitian dan Pengembangan Hasil Hutan, Bogor
} 
Produktivitas yang dicapai dengan dilakukannya penyempurnaan berupa penambahan endless drum diperoleh hasil sebesar $5 \mathrm{~m}^{3} . \mathrm{hm} / \mathrm{jam}$ dan untuk muat/bongkar $50 \mathrm{~m}^{3} . \mathrm{m} / \mathrm{jam}$. Dengan biaya investasi sebesar Rp 100 juta, maka dengan biaya pemilikan dan pengoperasian alat berdasarkan perhitungan adalah sebesar Rp 60.175 per jam, sehingga biaya pengumpulan dan pemuatan kayu secara berurutan masing-masing adalah Rp 12.305 per $\mathrm{m}^{3}$.hm dan Rp 1.135 per $\mathrm{m}^{3} . \mathrm{m}$. Biaya ini jelas lebih efektif dan efisien dibanding cara konvensional yang besarnya mencapai masing-masing secara berurutan Rp 35.000 dan Rp 15.000 per m³ .

Kata kunci: Pengeluaran kayu, efektif, efisien, alat Expo-2000

\section{PENDAHULUAN}

Expo-2000 merupakan prototipe alat yang dirancang dapat memenuhi kegunaan serbaguna untuk pengumpulan kayu dengan cara disarad atau sistem kabel layang, serta dapat dipakai untuk muat bongkar kayu. Pembangunannya diawali pada tahun 2000/2001, yang saat itu dimaksudkan hanya sebagai alat muat bongkar. Namun, karena mesin penggeraknya saat itu relatif kecil dan konstruksi rantai kurang seimbang, pada uji coba alat mengalami kerusakan. Oleh karena itu, prototipe dirancang ulang dan fungsinya dibuat menjadi serbaguna yakni dapat dipakai untuk kegiatan muat/bongkar dan penyaradan kayu.

Pada tahun berikutnya daya mesin ditingkatkan dari 11 tenaga kuda (PK) menjadi 24 PK, sedang roda penyangga dari sistem 3 roda dengan salah satunya berukuran kecil diubah menjadi 4 roda yang seukuran. Tujuannya agar saat pindah lokasi terutama pada tanah-tanah becek, tidak terlalu menjadi kendala.

Pada perbaikan lebih lanjut, tiang yang dipasang dengan sistem knock down dibuat menjadi sistem satu unit utuh, sementara perbaikan dilakukan pula pada sistem kabel penarik, sehingga kayu dikumpulkan tidak hanya dengan cara disarad biasa (ground skidding), tetapi juga dapat dilakukan dengan sistem kabel layang (skyline).

Pada tahun 2004, konstruksi Expo-2000 ditambah dengan satu buah drum endless yang berfungsi untuk menarik, sedang drum yang lama difungsikan untuk mengangkat kayu. Namun, fungsi kedua drum itu tidak dapat dijalankan secara bersamaan, karena penggeraknya sama. Bila drum endless dijalankan maka fungsi drum penarik tidak bisa digunakan, dan sebaliknya. Namun demikian, diharapkan dengan penambahan drum ini fungsinya lebih meningkat, sehingga pengeluaran kayu berikut pemuatannya ke atas truk semakin efektif dan efisien serta dapat dioperasikan pada skala luas, khususnya pada lapangan dengan kondisi medan yang sulit.

Tujuan penelitian ini ialah mengetahui kemampuan dan kelancaran (performance) penggunaan hasil rekayasa alat Exp-2000 dalam pengeluaran dan muat bongkar kayu setelah dilakukan penyempurnaan dengan menambahkan drum endless. Sasaran penelitian ialah membangun satu unit alat serbaguna yang dapat dipakai untuk mengeluarkan kayu pada medan yang sulit bersama-sama dengan kegunaan untuk pemuatan kayu ke atas truk yang efektif dan efisien serta ramah lingkungan. 


\section{BAHAN DAN METODE}

\section{A. Tempat dan Waktu}

Uji coba dilakukan di petak 23B RPH Ciguha, BKPH Cikawung, KPH Sukabumi. Uji coba dilakukan pada akhir bulan Oktober hingga awal Nopember 2004, saat frekuensi hujan sudah mulai meningkat.

\section{B. Bahan dan Alat}

Bahan dan alat yang dipakai yaitu Expo-2000 yang disempurnakan, seperangkat kunci dan alat bantu lain, solar dan oli, tally sheet untuk pencatatan data, kamera dengan film, stop watch, meteran, tambang, kompas dan sarung tangan.

\section{Pemasangan Jalur Kabel}

Sebelum uji coba dilakukan, dipilih lokasi yang memadai untuk pemasangan jalur kabel dan posisi mesin. Agar tidak mengganggu kelancaran uji coba, pohon dan semak belukar yang ada di jalur kabel harus dibersihkan dan pohon yang menghalangi ditebang. Kegiatan lainnya yakni pemasangan katrol utama pada dua pohon terpilih, katrol untuk pengangkat muatan serta penarik (haul back), serta penarikan dan pemasangan kabel utama.

\section{Persiapan mesin penarik kabellayang}

Persiapan ini dilakukan pada setiap akan uji coba, meliputi pengecekan kabel, bendera komando pengeluaran kayu, pemasangan bendera indikator jarak, pengetesan fungsi stop watch, pengecekan bahan bakar dan oli. Pemeriksaan lain dilakukan terhadap penahan tiang, sistem rem, jalannya mesin, serta tenaga kerja dan pembagian tugas.

\section{Penarikan kayu}

Uji coba pengeluaran kayu dilakukan dengan terlebih dahulu disiapkan tiga rantai pengikat, tambang penarik katrol dan bendera untuk kendali operator mesin. Kayu yang ditarik adalah potongan kayu sisa pertukangan yang tidak dapat dipikul karena berat, medan curam dan licin. Potongan batang ini adalah bekas batang pohon yang disadap dan biasanya digolongkan sebagai kayu bakar dengan panjang sortimen dapat mencapai $4 \mathrm{~m}$. Kayu bulat yang keluar dari petak tebangan dan dihitung pengupahannya oleh Perhutani adalah hanya kayu yang utuh panjang 1-2 $\mathrm{m}$ berdimeter $15 \mathrm{~cm}$ ke atas.

\section{Pengumpulan Data}

Data yang dikumpulkan meliputi jenis dan ukuran kayu (diameter dan panjang dalam $\mathrm{cm})$, jarak (m), waktu pemuatan, pembongkaran dan pengumpulan masing-masing sortimen (menit) serta kelemahan kinerja alat. 


\section{E. Pengolahan Data}

1. Menghitung produktivitas kerja pemuatan, pembongkaran dan pengumpulan.

$$
\mathrm{PK}=\frac{\mathrm{V} \times \mathrm{J}}{\mathrm{W}}
$$

Keterangan : PK = Produktivitas kerja $\left(\mathrm{m}^{3} \mathrm{~m} / \mathrm{menit}\right), \mathrm{V}=$ Volume muat kayu $\left(\mathrm{m}^{3}\right), \mathrm{W}=$ Waktu kerja efektif (menit), J = Jarak sarad atau muat (m)

2. Menghitung volume kayu

$$
\mathrm{V}=0,25 \times 3,14(\mathrm{Dp}+\mathrm{Du}) 2 / 2 \times \mathrm{L}
$$

Keterangan : $\mathrm{V}=$ Volume kayu $\left(\mathrm{m}^{3}\right), \mathrm{Dp}=$ Diameter pangkal $(\mathrm{cm}), \mathrm{Du}=$ Diameter ujung $(\mathrm{cm})$ dan $\mathrm{L}=$ Panjang $(\mathrm{m})$

3. Analisis biaya

a. Biaya penyusutan (Bp)

$$
\mathrm{Bp}=\frac{\mathrm{M}-\mathrm{R}}{\mathrm{Nxt}}
$$

Di mana: $\mathrm{Bp}=$ Penyusutan $(\mathrm{Rp} / \mathrm{jam}) ; \mathrm{M}=$ Investasi alat $(\mathrm{Rp}) ; \mathrm{R}=$ Nilai alat bekas $(10 \%$ dari harga baru); $\mathrm{N}=$ Umur pakai alat (10 tahun) dan $\mathrm{t}=$ Waktu kerja alat (1.000 $\mathrm{jam} / \mathrm{tahun})$

b. Bunga modal (Bm)

$$
\mathrm{Bm}=\frac{\frac{\{(\mathrm{M}-\mathrm{R})(\mathrm{N}+1)+\mathrm{R}\} \times 0,0 \mathrm{p}}{2}}{\mathrm{t}}
$$

di mana : $\mathrm{B}=$ Bunga modal $(\mathrm{Rp} / \mathrm{jam}) ; \mathrm{p}=$ Suku bunga per tahun (\% per tahun) dan $\mathrm{t}=$ Waktu kerja (tahun)

c. Biaya perawatan (Bpr) (Anonim, 1974)

$$
\mathrm{BP}=\frac{\text { Harga alat }(\mathrm{Rp}) \times 0,1}{1.000 \mathrm{jam}}
$$

d. Biaya bahan bakar (Bb)

$$
\mathrm{Bb}=\text { Penggunaan (liter/jam) } \mathrm{x} \text { harga per liter (Rp/lt) }
$$


e. Biaya oli dan pelumas (Bo) (Anonim, 1974)

$$
\text { Bo }(\mathrm{Rp} / \mathrm{jam})=\frac{\text { Harga alat }(\mathrm{Rp}) \times 0,005}{1.000 \mathrm{jam}}
$$

$$
\text { Gaji (Rp/bulan) }
$$

f. Biaya operator $(\mathrm{Rp} / \mathrm{jam})=$

(Bop)

g. Biaya tenaga pembantu $(\mathrm{Rp} / \mathrm{jam})=\frac{\mathrm{Rp} 15.000 / \text { hari }}{\text { (Btp) }}$

h. $\operatorname{Pajak}(\mathrm{Pj})=\frac{\mathrm{Hx} 0,6 \times 2 \%}{1.000 \mathrm{jam}}$

i. $\quad$ Asuransi (As) $=\frac{\mathrm{Hx} 0,6 \times 3 \%}{1.000 \mathrm{jam}}$

j. Biaya operasi pengeluaran kayu $(\mathrm{Bpb})$

$$
\mathrm{Bpb}=\frac{\mathrm{Bp}+\mathrm{Bm}+\mathrm{Brm}+\mathrm{Bbm}+\mathrm{Bo}+\mathrm{Bop}+\mathrm{Btp}+\mathrm{Pj}+\mathrm{As}}{\mathrm{PK}}
$$

di mana $: \mathrm{Bpb}=$ Biaya pengeluaran kayu $\left(\mathrm{Rp} / \mathrm{m}^{3}\right) ; \mathrm{Bpm}=$ Biaya penyusutan alat muat bongkar (Rp/jam); Bm = Biaya modal alat (Rp/jam); Brm = Biaya perawatan alat (Rp/jam); Bbm= Biaya bahan bakar (solar) $(\mathrm{Rp} / \mathrm{jam}) ; \mathrm{Bo}=$ Biaya oli $(\mathrm{Rp} / \mathrm{jam}) ;$ Bop $=$ Biaya operator $(\mathrm{Rp} / \mathrm{jam}) ;$ Btp = Biaya tenaga pembantu $(\mathrm{Rp} / \mathrm{jam}) ; \mathrm{Pj}=$ Pajak, As = Asuransi; dan $\mathrm{PK}=$ Produktivitas kerja $\left(\mathrm{m}^{3} / \mathrm{jam}\right)$.

\section{HASIL DAN PEMBAHASAN}

\section{A. Keadaan Lokasi Penelitian}

Lokasi uji coba dilakukan di petak 23B, yang berada di igir bukit berjarak kurang lebih 0,5 - $3 \mathrm{~km}$ dari kampung terdekat. Keadaan medannya tergolong unit lahan bergelombang ringan sampai berat, dengan jenis tanah podsolik merah kuning. Lokasi uji coba dinilai cukup memadai karena lapangannya cukup curam dengan kemiringan lapangan antara $20-35^{\circ}$, dan panjang lereng antara 50-70 meter. Tegakan yang dipakai sebagai uji coba adalah dari jenis Tusam (Pinus merkusii Young et de Vries) yang masih tergolong baik dan rapat, termasuk kelas umur II dengan jarak tanam 3 × 2 m. Saat itu sedang dilakukan tebang penjarangan dan juga disadap untuk diambil getahnya. Diameter pohon bervariasi antara $20-46 \mathrm{~cm}$. 


\section{B. Uji Coba Awal}

Uji coba dilakukan dengan panjang bentang kabel sejauh 140 meter. Para pekerja yang ikut pada uji coba belum berpengalaman, sehingga pada awalnya tidak memahami proses pengeluaran kayu pada sistem kabel layang. Produktivitas kerjanya rata-rata pada tahap awal masih relatif rendah dengan capaian sebesar $1,369 \mathrm{~m}^{3} . \mathrm{hm} / \mathrm{jam}$. Hal ini menyebabkan kinerja menjadi lambat dan terjadi variasi cukup besar terutama dalam waktu pengikatan kayu dan pelepasan muatan. Selain itu selama proses penarikan masih sering terjadi muatan naik turun.

Tabel1. Hasil uji coba tahap awal pengumpulan kayu menggunakan sistem kabel Table 1. Results of initial test on log collecting using cable system

\begin{tabular}{|c|c|c|c|c|c|c|c|c|c|c|c|}
\hline \multirow[t]{2}{*}{ No } & \multicolumn{5}{|c|}{ Waktu (Time), menit (minute) } & \multirow[b]{2}{*}{$\begin{array}{c}\text { Jarak } \\
\text { (Distance) }) \\
\mathrm{m}\end{array}$} & \multirow[b]{2}{*}{$\begin{array}{c}\text { Diamete } \\
\text { rata2 } \\
(\text { Mean }), \\
\mathrm{cm}\end{array}$} & \multirow[b]{2}{*}{$\begin{array}{c}\text { Panjang } \\
(\text { Length), } \\
\mathrm{m}\end{array}$} & \multirow[b]{2}{*}{$\begin{array}{c}\text { Volume } \\
\left(\mathrm{m}^{3}\right)\end{array}$} & \multirow[b]{2}{*}{$\begin{array}{c}\text { Total } \\
\left(\mathrm{m}^{3}\right)\end{array}$} & \multirow[b]{2}{*}{$\begin{array}{l}\text { Produktivitas } \\
\text { (Productivity), } \\
\mathrm{m}^{3} \cdot \mathrm{hm} / \mathrm{jam} \\
\left(\mathrm{m}^{3} \cdot \mathrm{hm} / \mathrm{hr}\right)\end{array}$} \\
\hline & $\begin{array}{l}\text { Bongkar } \\
\text { (Unloading) }\end{array}$ & $\begin{array}{l}\text { Muatan } \\
\text { kosong } \\
\text { (Empty } \\
\text { carriage) }\end{array}$ & $\begin{array}{c}\text { Ikat } \\
\text { muatan } \\
\text { (Load } \\
\text { tightened) }\end{array}$ & $\begin{array}{c}\text { Tarik } \\
\text { muatan } \\
\text { (Pulling } \\
\text { of load) }\end{array}$ & Total & & & & & & \\
\hline 1 & 1 & 0,75 & 2,5 & 2,75 & 7 & 120 & 25 & 1,1 & 0,0539 & 0,0539 & 0,7771 \\
\hline 2 & 0,1 & 1 & 1 & 0,5 & 2,6 & 120 & 30 & 2 & 0,1413 & 0,1413 & 3,9129 \\
\hline 3 & 0,5 & 1,15 & 0,867 & 2,4 & 4,917 & 120 & 25 & 2 & 0,0981 & 0,0981 & 1,4369 \\
\hline 4 & 0,5 & 1,1 & 0,75 & 2,66 & 5,01 & 120 & 15 & 1,2 & 0,0212 & 0,0212 & 0,3046 \\
\hline 5 & 0,1 & 1,1 & 1,283 & 2,3 & 4,783 & 110 & 18 & 1,2 & 0,0305 & 0,0305 & 0,4211 \\
\hline 6 & 0,1333 & 1,033 & 0,367 & 2,583 & 4,116 & 100 & 25 & 2 & 0,0981 & 0,0981 & 1,4303 \\
\hline 7 & 0,0833 & 0,917 & 0,5 & 2,633 & 4,133 & 110 & 25 & 1 & 0,0490 & 0,0490 & 0,7834 \\
\hline \multirow[t]{2}{*}{8} & 0,8167 & 0,767 & 0,267 & 2,33 & 4,18 & 110 & 25 & 1 & 0,0490 & 0,1118 & 1,4597 \\
\hline & & & & & & & 20 & 2 & 0,0628 & & \\
\hline 9 & 0,6 & 0,6 & 0,933 & 2,583 & 4,716 & 100 & 20 & 2 & 0,0628 & 0,0628 & 0,7989 \\
\hline \multirow[t]{3}{*}{10} & 0,2 & 0,567 & 0,433 & 2,533 & 3,733 & 110 & 30 & 1,9 & 0,1342 & 0,1342 & 2,3732 \\
\hline & & & & & & & & & & $\begin{array}{l}\text { Jumlah } \\
\text { (Tota) }\end{array}$ & 13,6986 \\
\hline & & & & & & & & & & $\begin{array}{l}\text { Rata }^{2} \\
(\text { Mean) }\end{array}$ & 1,3698 \\
\hline
\end{tabular}

Tabel 1 memperlihatkan prestasi kerja sebesar 1,369 $\mathrm{m}^{3}$ yang tergolong rendah. Ini terjadi karena waktu banyak dipakai untuk mengikat kayu, sementara para pekerja seharusnya segera melakukan pengikatan agar saat kereta muatan datang kayu tinggal diikat. Waktu pengikatan muatan kayu bervariasi antara 1-4 menit.

\section{Uji Coba Lanjutan}

Pada uji coba berikutnya, Tim sudah mulai mengetahui cara kerja, sehingga prestasi kerja tim mulai dapat meningkat. Peningkatan produktivitas kerja rata-rata $1,3 \mathrm{~m}^{3} \cdot \mathrm{hm} / \mathrm{jam}$ menjadi 1,65 $\mathrm{m}^{3} \cdot \mathrm{hm} /$ jam seperti terlihat pada Tabel 2 dan lebih meningkat lagi sebagaimana disajikan dalam Tabel3. 
Tabel 2. Hasil uji coba tahap dua pengumpulan kayu menggunakan sistem kabel Table 2. Results of the second test on log collecting using cable system

\begin{tabular}{|c|c|c|c|c|c|c|c|c|c|}
\hline \multirow[b]{2}{*}{ No } & \multicolumn{3}{|c|}{$\begin{array}{c}\text { Waktu (Time), } \\
\text { menit (minutes) }\end{array}$} & \multirow[b]{2}{*}{$\begin{array}{c}\text { Jarak } \\
\text { (Distance) } \\
\mathrm{m}\end{array}$} & \multirow[b]{2}{*}{$\begin{array}{l}\text { Diameter } \\
(\mathrm{cm})\end{array}$} & \multirow{2}{*}{$\begin{array}{c}\text { Panjang } \\
(\text { Length }), \\
\mathrm{m}\end{array}$} & \multirow{2}{*}{$\begin{array}{l}\text { Jumlah } \\
\text { batang } \\
\text { (Number } \\
\text { of logs) }\end{array}$} & \multirow[b]{2}{*}{$\begin{array}{l}\text { Volume } \\
\left(\mathrm{m}^{3}\right)\end{array}$} & \multirow{2}{*}{$\begin{array}{c}\text { Produktivitas } \\
\text { (Productivity), } \\
\mathrm{m}^{3} \cdot \mathrm{hm} / \mathrm{jam} \\
\left(\mathrm{m}^{3} \cdot \mathrm{hm} / \text { hour }\right)\end{array}$} \\
\hline & $\begin{array}{l}\text { Muatan } \\
\text { kosong } \\
(\text { Empty } \\
\left.\text { load })^{*}\right)\end{array}$ & $\begin{array}{c}\text { Muatan } \\
\text { isi } \\
\text { (Filled } \\
\left.\text { load })^{* *}\right)\end{array}$ & Total & & & & & & \\
\hline 1 & 1.82 & 4.25 & 6.07 & 75 & 29 & 3.00 & 1.00 & 0.191 & 2.516 \\
\hline 2 & 1.23 & 4.16 & 5.39 & 78 & 32 & 3.01 & 1.00 & 0.242 & 3.450 \\
\hline 3 & 1.17 & 4.93 & 6.10 & 76 & 28 & 2.00 & 1.00 & 0.123 & 1.593 \\
\hline 4 & 1.29 & 4.05 & 5.34 & 77 & 25 & 2.50 & 1.00 & 0.147 & 2.147 \\
\hline 5 & 1.84 & 4.58 & 6.42 & 78 & 11 & 2.50 & 3.00 & 0.083 & 0.990 \\
\hline 6 & 1.73 & 4.32 & 6.05 & 72 & 14 & 2.00 & 1.00 & 0.086 & 1.185 \\
\hline 7 & 1.53 & 2.92 & 4.45 & 70 & 19 & 2.20 & 1.00 & 0.062 & 1.199 \\
\hline 8 & 1.53 & 2.68 & 4.22 & 68 & 16 & 2.80 & 1.00 & 0.056 & 1.176 \\
\hline 9 & 2.54 & 2.65 & 5.19 & 68 & 27 & 1.20 & 1.00 & 0.069 & 1.167 \\
\hline 10 & 1.07 & 2.90 & 3.97 & 66 & 29 & 1.20 & 1.00 & 0.079 & 1.815 \\
\hline 11 & 1.68 & 6.00 & 7.68 & 62 & 15 & 1.20 & 3.00 & 0.056 & 0.704 \\
\hline 12 & 1.50 & 2.08 & 3.58 & 61 & 13 & 3.50 & 1.00 & 0.100 & 2.734 \\
\hline 13 & 1.83 & 13.12 & 14.95 & 60 & 30 & 1.20 & 1.00 & 0.085 & 0.567 \\
\hline 14 & 1.85 & 5.23 & 7.08 & 60 & 15 & 2.50 & 1.00 & 0.097 & 1.373 \\
\hline 15 & 1.77 & 2.33 & 4.10 & 60 & 20 & 1.20 & 1.00 & 0.038 & 0.917 \\
\hline 16 & 1.58 & 3.48 & 5.07 & 80 & 22 & 2.00 & 1.00 & 0.076 & 1.124 \\
\hline 17 & 1.50 & 3.80 & 5.30 & 80 & 30 & 1.20 & 1.00 & 0.085 & 1.199 \\
\hline 18 & 1.25 & 2.40 & 3.65 & 80 & 31 & 2.00 & 1.00 & 0.151 & 3.099 \\
\hline 19 & 1.75 & 4.00 & 5.75 & 80 & 30 & 1.20 & 1.00 & 0.085 & 1.105 \\
\hline 20 & 1.58 & 3.97 & 5.55 & 80 & 29 & 1.80 & 1.00 & 0.119 & 1.605 \\
\hline 21 & 1.52 & 2.53 & 4.05 & 80 & 30 & 1.20 & 1.00 & 0.085 & 1.570 \\
\hline 22 & 2.52 & 4.75 & 7.27 & 80 & 29 & 1.20 & 2.00 & 0.148 & 1.525 \\
\hline 23 & 2.35 & 3.02 & 5.37 & 90 & 30 & 2.20 & 1.00 & 0.155 & 1.931 \\
\hline 24 & 1.90 & 2.90 & 4.80 & 100 & 30 & 1.20 & 1.00 & 0.085 & 1.059 \\
\hline 25 & 2.35 & 4.43 & 6.78 & 90 & 15 & 3.00 & 3.00 & 0.131 & 1.287 \\
\hline 26 & 1.68 & 2.07 & 3.75 & 70 & 13 & 2.50 & 3.00 & 0.106 & 2.411 \\
\hline 27 & 1.85 & 5.12 & 6.97 & 80 & 27 & 3.00 & 1.00 & 0.172 & 1.847 \\
\hline 28 & 1.48 & 2.08 & 3.57 & 80 & 30 & 1.00 & 1.00 & 0.071 & 1.485 \\
\hline $\begin{array}{l}\text { Jumlah } \\
\text { (Total) }\end{array}$ & 47.70 & 110.75 & 158.45 & 2101 & 669 & 55.51 & 37.00 & 2.979 & 44.78 \\
\hline $\begin{array}{l}\text { Rata2 } \\
\text { (Mean) }\end{array}$ & 1.70 & 3.96 & 5.66 & 75.04 & 23.89 & 1.98 & 1.32 & 0.106 & 1.60 \\
\hline
\end{tabular}

Keterangan (Remarks) : *) Meliputi penurunan, pelepasan ikatan kayu dan pengembalian kereta angkut (Covering the lowering of load, disengaging of hook, and hauling of carriag); **) Meliputi pemasangan, dan pengembalian kereta angkut (Covering the assembling of load and returning of carriage) 
Tabel 3. Prestasi kerja pada uji coba setelah ada pengenalan dan pelatihan Table 3. Working performance after training phase

\begin{tabular}{|c|c|c|c|c|c|c|c|}
\hline No & $\begin{array}{l}\text { Jarak ke TPn } \\
\text { (Distance to } \\
\text { landing site) } \\
\text { (m) }\end{array}$ & $\begin{array}{l}\text { Waktu } \\
\text { (Time) } \\
\text { (menit) } \\
\text { (minute) }\end{array}$ & $\begin{array}{l}\text { Diameter } \\
(\mathrm{cm})\end{array}$ & $\begin{array}{c}\text { Panjang } \\
\text { (Length) } \\
\text { (m) }\end{array}$ & $\begin{array}{l}\text { Volume total } \\
\qquad\left(\mathrm{m}^{3}\right)\end{array}$ & $\begin{array}{c}\text { Prod kerja } \\
\text { (Productivity) } \\
\left(\mathrm{m}^{3} \cdot \mathrm{hm} / \mathrm{jam}\right) \\
\left(\mathrm{m}^{3} . \mathrm{hm} / \text { hour }\right)\end{array}$ & $\begin{array}{c}\text { Ket. } \\
\text { (Remarks) }\end{array}$ \\
\hline 1 & 60 & 2 & $17 ; 24$ & 1,2 & 0,0815 & 4,0742 & \\
\hline 2 & 60 & 3,75 & $13 ; 14$ & 4 & 0,1146 & 3,0563 & \\
\hline 3 & 60 & 3 & 29 & 1,2 & 0,0792 & 2,6407 & \\
\hline 4 & 60 & 3,75 & $26 ; 26$ & 1,2 & 0,0637 & 1,6981 & \\
\hline 5 & 60 & 3,93 & 34 & 2,5 & 0,2269 & 5,7726 & \\
\hline 6 & 60 & 3,25 & 15 & 4 & & & \\
\hline 7 & 80 & 3,91 & $17 ; 18$ & 2,5 & 0,1203 & 2,3076 & \\
\hline 8 & 85 & 4,083 & 26 & 3 & 0,1592 & 2,9243 & \\
\hline 9 & 100 & 3,75 & $24 ; 23$ & 1,$2 ; 1,5$ & 0,1165 & 1,8648 & \\
\hline 10 & 100 & 3,8667 & 27 & 1,8 & 0,1030 & 1,5984 & \\
\hline 11 & 104 & 2,783 & 27 & 1 & 0,0572 & 1,2338 & \\
\hline 12 & 115 & 8,93 & 33 & 3 & 0,2565 & 1,9816 & $\begin{array}{l}\text { ikatan lepas } \\
\text { (Loose tying) }\end{array}$ \\
\hline 13 & 120 & 5 & 15 & 5 & 0,0883 & 1,2717 & \\
\hline 14 & 38 & 4 & 30 & 1,3 & 0,0918 & 4,5923 & \\
\hline 15 & 38 & 2,25 & $18 ; 17$ & $4 ; 3$ & 0,1698 & 15,0929 & \\
\hline 16 & 35 & 2 & $30 ; 15$ & 2 & 0,2296 & 22,9613 & \\
\hline 17 & 40 & 3,25 & 26 & 2 & 0,1061 & 6,5312 & \\
\hline 18 & 25 & 2,5 & 34 & 2 & 0,1815 & 17,4232 & \\
\hline 19 & 23 & 2 & 28 & 2 & 0,1231 & 16,0550 & \\
\hline 20 & 20 & 2,4 & 35 & 1,2 & 0,1154 & 14,4244 & \\
\hline 21 & 20 & 3,15 & $18 ; 22$ & $2 ; 1,5$ & 0,1079 & 10,2723 & \\
\hline 22 & 20 & 2,6 & 29 & 3 & 0,1981 & 22,8526 & \\
\hline 23 & 20 & 2,7833 & 25 & 2,5 & 0,1227 & 13,2206 & \\
\hline 24 & 30 & 2,5667 & 33 & 2 & 0,1710 & 19,9836 & \\
\hline 25 & 31 & 2 & 27 & 1 & 0,0572 & 6,8672 & \\
\hline 27 & 27 & 2,75 & 24 & 4 & 0,1809 & 19,7306 & \\
\hline & & & & \multicolumn{2}{|c|}{ Jumlah (Total) } & 220,4310 & \\
\hline & & & & \multicolumn{2}{|c|}{$\operatorname{Rata}^{2}$ (Mean) } & 8,1641 & \\
\hline
\end{tabular}

Dari Tabel 3 terlihat bahwa setelah mulai mengenal dan memahami prinsip-prinsip kerja dalam model tim, pengeluaran kayu semakin cepat dan produktif. Data menunjukkan ratarata prestasi kerjanya dapat mencapai $8,1641 \mathrm{~m}^{3} . \mathrm{hm} / \mathrm{jam}$. Bila dirata-ratakan dengan prestasi kerja sebelumnya, maka diperoleh sekitar 5-6 $\mathrm{m}^{3} . \mathrm{hm} / \mathrm{jam}$. Kondisi ini hampir mencapai 2 kali prestasi alat dengan kondisi tahun lalu yang rata-ratanya mencapai $3,6 \mathrm{~m}^{3} . \mathrm{hm} / \mathrm{jam}$. Bila dalam satu hari ada 6 jam kerja minimal, maka produktivitas kerja dapat mencapai $30-36 \mathrm{~m}^{3} . \mathrm{hm} /$ hari. Untuk 8 jam kerja sedikitnya dicapai $40-50 \mathrm{~m}^{3} . \mathrm{hm} /$ hari. 
Apabila dibandingkan dengan cara manual atau dipikul (Tabel 4), yang berdasarkan hasil pengamatan tahun lalu prestasi kerjanya per tim dengan tenaga 2 - 4 orang hanya mampu mendapatkan sebanyak $0,49 \mathrm{~m}^{3} \cdot \mathrm{hm} / \mathrm{jam}$. Bila waktu kerja efektif adalah 6 jam per hari, berarti volume kayu yang dapat dikumpulkan hanya sebanyak $\pm 3 \mathrm{~m}^{3}$. Pada kenyataan, volume yang tercapai malah kurang dari jumlah volume tersebut, karena produktivitasnya menurun seiring makin lesunya tenaga. Apalagi lokasi yang harus dihadapi adalah lapangan naik turun dengan kelerengan hampir mendekati 60\%, sehingga jangankan membawa beban (memikul), jalan bebas tanpa bebanpun sudah merasa kepayahan. Dengan demikian kinerja alat Expo-2000 dapat dikatakan cukup produktif.

Tabel 4. Prestasi kerja pengumpulan kayu dengan cara manual (dipikul) Table 4. Working performance on log collection using manual(sbouldering manner)

\begin{tabular}{|c|c|c|c|c|c|c|c|c|c|c|}
\hline $\begin{array}{l}\text { Rit } \\
(\text { Trip })\end{array}$ & $\begin{array}{c}\varnothing \\
(\mathrm{cm})\end{array}$ & $\begin{array}{c}\text { Panjang } \\
\text { (Length), } \\
\mathrm{cm}\end{array}$ & $\begin{array}{c}\text { Volume } \\
\left(\mathrm{m}^{3}\right)\end{array}$ & $\begin{array}{c}\text { Persiapan } \\
\text { (Preparation), } \\
\text { detik (second) }\end{array}$ & $\begin{array}{l}\text { Pengumpulan } \\
\text { Collectng) } \\
\text { detik (secont) }\end{array}$ & $\begin{array}{c}\text { Kembali } \\
\text { (Return) } \\
\text { detik }\end{array}$ & $\begin{array}{l}\text { Jumlah } \\
\text { (Total), } \\
\text { menit } \\
\text { (minute) }\end{array}$ & $\begin{array}{c}\text { Jarak } \\
(\text { Distance }) \\
\mathrm{m}\end{array}$ & $\begin{array}{c}\text { Jumlah } \\
\text { batang } \\
\text { (Number } \\
\text { of wood } \\
\text { pieces) }\end{array}$ & $\begin{array}{c}\text { Ket. } \\
\text { (Remark) }\end{array}$ \\
\hline 1 & 34 & 340 & 0,25 & $2: 55$ & $12: 17$ & 7.02 & 22,23 & 150 & 1 & $\begin{array}{l}4 \text { org } \\
(M e n)\end{array}$ \\
\hline 2 & 23 & 220 & 0,09 & $2: 13$ & $8: 13$ & 6.56 & 17,37 & 150 & 1 & $\begin{array}{c}2 \text { org } \\
\text { (men) }\end{array}$ \\
\hline 3 & 23 & 230 & 0,10 & $2: 25$ & $7: 50$ & 6.56 & 17,18 & 150 & 1 & $\begin{array}{l}2 \text { org } \\
(m e n)\end{array}$ \\
\hline 4 & 24 & 220 & 0,10 & $3: 00$ & $7: 12$ & 6.36 & 16,80 & 150 & 1 & $\begin{array}{l}2 \text { org } \\
(m e n)\end{array}$ \\
\hline 5 & 21 & 200 & 0,07 & $2: 55$ & $6: 59$ & 6.35 & 16,48 & 150 & 1 & $\begin{array}{c}1 \text { Org } \\
(m e n)\end{array}$ \\
\hline 6 & 19 & 180 & 0,05 & $2: 59$ & 7:00 & 6.34 & 16,55 & 150 & 1 & $\begin{array}{l}1 \text { org } \\
(m e n)\end{array}$ \\
\hline 7 & 30 & 230 & 0,16 & 1:04 & $11: 57$ & 6.32 & 19,55 & 150 & 1 & $\begin{array}{l}4 \text { org } \\
(m e n)\end{array}$ \\
\hline 8 & 17 & 380 & 0,09 & $1: 25$ & $12: 17$ & 7.18 & 21,00 & 150 & 1 & $\begin{array}{l}4 \text { org } \\
(m e n)\end{array}$ \\
\hline 9 & 20 & 350 & 0,11 & $0: 49$ & $10: 58$ & 8.10 & 19,95 & 150 & 1 & $\begin{array}{l}4 \text { org } \\
(m e n)\end{array}$ \\
\hline 10 & 10 & 150 & 0,01 & $2: 56$ & $15: 15$ & 7.56 & 26,12 & 150 & 1 & $\begin{array}{c}4 \text { org } \\
(m e n)\end{array}$ \\
\hline 11 & 31 & 240 & 0,18 & $2: 10$ & $12: 50$ & 7.36 & 22,60 & 150 & 1 & $\begin{array}{c}2 \text { org } \\
(m e n)\end{array}$ \\
\hline 12 & 17 & 410 & 0,09 & $3: 40$ & $12: 59$ & 7.26 & 24,08 & 150 & 1 & $\begin{array}{l}2 \text { org } \\
(m e n)\end{array}$ \\
\hline \multicolumn{3}{|c|}{ Rata-rata (Mean) } & 0,11 & & & & 20,0 & & 1 & \\
\hline \multicolumn{3}{|c|}{$\begin{array}{c}\text { Produktivitas kerja } \\
\text { (Work producticity), } \\
\mathrm{m}^{3} . \mathrm{hm} / \text { jam } \\
\left(\mathrm{m}^{3} . \mathrm{hm} / \text { hour }\right)\end{array}$} & 0,49 & & & & & & & \\
\hline
\end{tabular}

Keterangan $($ Remarke) $:$ Org = Orang $($ Men $)$ 


\section{Kegiatan Muat dan Bongkar}

Kegiatan muat kayu ke atas alat angkutan hanya dilakukan secara simulasi karena untuk pemuatan nampaknya sudah tidak ada lagi masalah. Bahkan kelebihan cara muat dari alat ini ialah bahwa kayu dapat sekaligus ditarik dari jarak cukup jauh untuk dimuat ke atas mobil pickup dan atau truk tanpa kendala berarti. Produktivitas muat kayu ke atas truk tahun lalu adalah rata-rata $53,41 \mathrm{~m}^{3} \cdot \mathrm{m} /$ jam dan pembongkaran $56,52 \mathrm{~m}^{3} \cdot \mathrm{m} / \mathrm{jam}$.

Tabel 5. Rata-rata produktivitas kerja muat bongkar kayu dengan alat Expo-2000 Table 5. The average productivity of log loading/unloading using Expo-2000

\begin{tabular}{|c|c|c|c|c|c|c|c|c|c|c|}
\hline $\begin{array}{c}\text { Nomor } \\
\text { ulangan } \\
\text { (Replication } \\
\text { number) }\end{array}$ & \begin{tabular}{|l|} 
Jumlah \\
tarikan \\
(Number \\
of pulling
\end{tabular} & $\begin{array}{c}\text { Pema- } \\
\text { sangan } \\
(\text { Setting up }), \\
\text { detik } \\
\text { (second) }\end{array}$ & $\begin{array}{c}\text { Pena- } \\
\text { rikan } \\
\text { (Pulling), } \\
\text { detik } \\
\text { (second) }\end{array}$ & $\begin{array}{c}\text { Pele- } \\
\text { pasan } \\
\text { (Disengaging), } \\
\text { detik } \\
\text { (second })\end{array}$ & \begin{tabular}{|c|} 
Kembali \\
ke lokasi \\
pemuatan \\
(Back to \\
loading \\
area), \\
detik \\
(second) \\
\end{tabular} & $\begin{array}{c}\text { Jumlah } \\
\text { (Total), } \\
\text { detik } \\
\text { (second) }\end{array}$ & $\begin{array}{c}\text { Jarak } \\
\text { (Distance }), \\
\mathrm{m}\end{array}$ & $\begin{array}{c}\text { Jumlah } \\
\text { batang } \\
\text { (Number } \\
\text { of } \log \text { ) }\end{array}$ & $\begin{array}{c}\text { Volume } \\
\left(\mathrm{m}^{3}\right)\end{array}$ & $\begin{array}{c}\text { Produkti- } \\
\text { vitas } \\
\text { (Producti- } \\
\text { vity), } \\
\mathrm{m}^{3} / \text { jam } \\
\left(\mathrm{m}^{3} / \text { hour) }\right.\end{array}$ \\
\hline \multicolumn{11}{|c|}{ A. Pemuatan (Loading) } \\
\hline 1 & 9 & 13,22 & 19,89 & 8,11 & 8,33 & 49,56 & 3,00 & 2,11 & 0,23 & 50,18 \\
\hline 2 & 5 & 20,20 & 47,40 & 10,20 & 21,40 & 99,20 & 8,60 & 1,00 & 0,25 & 79,30 \\
\hline 3 & 40 & 11,53 & 27,23 & 7,85 & 10,35 & 56,95 & 4,78 & 1,48 & 0,10 & 30,76 \\
\hline $\begin{array}{l}\text { Jumlah } \\
\text { (Total) }\end{array}$ & 54 & 44,95 & 94,51 & 26,16 & 40,08 & 205,71 & 16,39 & 4,59 & 0,58 & 160,24 \\
\hline $\begin{array}{l}\text { Rata-rata } \\
(\text { Mean })\end{array}$ & 18,00 & 14,98 & 31,50 & 8,72 & 13,36 & 68,57 & 5,46 & 1,53 & 0,19 & 53,41 \\
\hline \multicolumn{11}{|c|}{ B. Bongkar (Unloading) } \\
\hline 1 & 5 & 9,80 & 23,80 & 7,20 & 9,80 & 50,60 & 4,00 & 1,00 & 0,19 & 55,51 \\
\hline 2 & 11 & 13,73 & 19,64 & 11,73 & 8,27 & 53,36 & 4,00 & 2,09 & 0,19 & 57,53 \\
\hline $\begin{array}{l}\text { Jumlah } \\
\text { (Total) }\end{array}$ & 16 & 23,53 & 43,44 & 18,93 & 18,07 & 103,96 & 8,00 & 3,09 & 0,38 & 113,04 \\
\hline $\begin{array}{l}\text { Rata-rata } \\
(\text { Mean })\end{array}$ & 8 & 11,76 & 21,72 & 9,46 & 9,04 & 51,98 & 4,00 & 1,55 & 0,19 & 56,52 \\
\hline
\end{tabular}

Keterangan (Remarks) : Pemuatan 1 dan 2 pada mobil pick-up Colt (Loading numbers 1 and 2 were carried out using Colt's pick-up vechicle); pemuatan nomor 3 dilakukan dengan mobil truk Toyota Dyna PS 120 berkapasitas $6 \mathrm{~m}^{3}$ (Loading numbers 3 were carried out using Toyota Dyna PS 120's truck vechicle with $6 \mathrm{~m}^{3}$ capacity); bongkar No 1 dan 2 hanya dilakukan pada mobil pick-up Colt (All unloading works (number 1 and 2) were carried out using only Colt'spick-up vechicle)

\section{E. Jam Kerja Mesin dan Penggunaan Bahan Bakar}

Hasil pengamatan jam kerja mesin dan penggunaan bahan bakar disajikan pada Tabel 6. 
Tabel 6. Penggunaan bahan bakar dan jam kerja mesin Table 6. Consumption of fuel and working bours of machine/equipment

\begin{tabular}{|c|c|c|c|c|c|}
\hline \multirow{2}{*}{ No } & \multirow{2}{*}{\begin{tabular}{|c|} 
Kegiatan dimulai \\
pada pukul \\
$($ Activities started at $)$ \\
jam (O'clock time)
\end{tabular}} & \multirow{2}{*}{$\begin{array}{l}\text { Kegiatan diakhiri } \\
\text { pukul } \\
\text { (Activities ended aA), } \\
\text { jam (O'clock time) }\end{array}$} & \multirow{2}{*}{$\begin{array}{c}\text { Lama kegiatan } \\
\text { (Duration of activitie), } \\
\text { jam (hours) }\end{array}$} & \multicolumn{2}{|c|}{$\begin{array}{l}\text { Pemakaian solar } \\
\text { (Fuel consumption) }\end{array}$} \\
\hline & & & & (Liter) & $\begin{array}{l}\text { jam/liter } \\
\text { (hour/liter) }\end{array}$ \\
\hline 1 & 12,29 & 16 & 3,31 & 3,6 & 1,087 \\
\hline 2 & 9,18 & 12,04 & 2,46 & 2,0 & 0,8131 \\
\hline 3 & 13,45 & 15 & 1,15 & 1,4 & 1,217 \\
\hline 4 & 8,46 & 11,05 & 2,19 & 1,8 & 0,822 \\
\hline 5 & 12,39 & 13,3 & 1,01 & 1,0 & 0,990 \\
\hline & \multicolumn{3}{|c|}{ Jumlah (Total) } & 9.8 & 4,930 \\
\hline & \multicolumn{3}{|c|}{ Rata-rata (Mean) } & & 0,986 \\
\hline
\end{tabular}

Penggunaan bahan bakar solar rata-rata 0,986 liter/jam hampir sama dengan kondisi tahun lalu (sebelum perbaikan). Penggunaan bahan bakar (Tabel 6) dibulatkan menjadi 1 liter per jam, sedang harga solar di lokasi saat itu sebesar Rp 1600, maka bila operasi berlangsung selama 8 jam/hari; berarti biaya untuk keperluan bahan bakar hanya sebesar Rp 14.800/hari. Berdasar penggunaan bahan bakar ini pengoperasian alat terlihat cukup efisien.

\section{F. Analisa Biaya}

Dasar analisis perhitungan biaya produksi pengumpulan maupun pemuatan kayu per m3 disajikan pada Tabel 7 dan Tabel 8.

Tabel 7. Perhitungan biaya pengumpulan kayu dengan alat Expo-2000 Table 7. Calculation of log collecting expenses using Expo-2000

\begin{tabular}{|c|c|c|c|}
\hline $\mathrm{No}$ & Uraian (Description) & Satuan (Value), Unit & $\mathrm{Rp}$ \\
\hline 1 & Harga alat (Price of tool) & Rp/unit & 100.000 .000 \\
\hline 2 & Upah operator (Operator wage) & Orang/bulan (Man/month) & 1.000.000 \\
\hline 3 & $\begin{array}{l}\text { Upah pembantu operator } \\
\text { (Assistant operator wage) }\end{array}$ & Orang/hari (Man/day) & 25.000 \\
\hline 4 & Hari kerja (Working day) & Hari/bulan (Day/month) & 20 \\
\hline 5 & Waktu kerja (Working hour) & Jam/hari (Hour/day) & 8 \\
\hline 6 & $\begin{array}{l}\text { Waktu kerja alat } \\
\text { (Working duration of tool) }\end{array}$ & Jam/tahun (Hour/year) & 1.000 \\
\hline 7 & Masa pakai alat (Life time duration) & Tahun (Year) & 10 \\
\hline 8 & $\begin{array}{l}\text { Bunga modal, asuransi dan pajak } \\
\text { (Interest, insurance and tax) }\end{array}$ & $\%$ & 18 \\
\hline 9 & Bahan bakar (Fued) & Liter/jam (literst/hour) & 1 \\
\hline 10 & Harga bahan bakar (Fuel price) & $\mathrm{Rp} /$ liter & 1.600 \\
\hline
\end{tabular}


Tabel 8. Komponen biaya pengeluaran kayu

Table 8. Log extraction component cost

\begin{tabular}{|c|l|r|}
\hline No & \multicolumn{1}{|c|}{ Biaya (Cost) } & \multicolumn{1}{|c|}{$\begin{array}{c}\text { Nilai (Value), } \\
\text { Rp/jam (Rp/ hour) }\end{array}$} \\
\hline 1 & Penyusutan (Depreciation cost) & 9.000 \\
2 & Asuransi (Insurance cost) & 1.800 \\
3 & Bunga (Interest rate) & 10.800 \\
4 & Pajak (Tax) & 1.200 \\
5 & Bahan bakar (Fuel cost) & 5.000 \\
6 & Oli pelumas (Grease and oil cost) & 500 \\
7 & Perbaikan/pemeliharaan (Maintenance cost) & 10.000 \\
8 & Biaya operator (Operator cost) & 9.375 \\
9 & Biaya upah tenaga kerja 4 orang (Wage cost for 4 workers) & 12.500 \\
\hline \multicolumn{2}{|c|}{ Total } & 60.175 \\
\hline
\end{tabular}

Dengan memperhitungkan rekayasa alat muat serbaguna yang bertenaga mesin baru dengan daya 24 PK dan penambahan drum Endless berikut perlengkapannya untuk satu unit seharga Rp 100 juta, maka biaya operasinya adalah sebesar Rp 60.175 per jam. Dengan perhitungan produktivitas pengumpulan kayu dapat dicapai rata-rata $5 \mathrm{~m}^{3} \cdot \mathrm{m} / \mathrm{jam}$, berarti biaya operasi per $\mathrm{m}^{3}$ adalah sebesar Rp 12.035,-. Sedang untuk pemuatan yang dapat mencapai rata-rata $53 \mathrm{~m}^{3} . \mathrm{m} / \mathrm{jam}$, maka biaya pemuatan ke atas mobil menjadi sekitar Rp 1.135 per $\mathrm{m}^{3} . \mathrm{m}$. Dengan nilai kurs untuk satu US $\$=\mathrm{Rp} 9.000$, maka untuk biaya operasi pengumpulan kayu setara US $\$ 1,33$ per $\mathrm{m}^{3}$.m dan untuk pemuatan senilai US $\$ 0,13$ per $\mathrm{m}^{3} . \mathrm{m}$. Biaya sebesar itu tentu lebih rendah dibanding menggunakan tenaga manusia yang pada kondisi sulit dilaporkan biaya pemikulan mencapai lebih dari Rp 50.000 per $\mathrm{m}^{3}$ bahkan pada kondisi sangat sulit lebih dari Rp 75.000 per $\mathrm{m}^{3}$.

Pemanenan kayu pada daerah berbukit dengan lereng curam atau memiliki akses yang rendah memerlukan biaya kegiatan yang mahal. Di samping berisiko dan tingkat produktivitasnya rendah maka pengeluaran kayu dengan cara manual (dipikul, digotong) bukan merupakan pilihan yang tepat dan ekonomis. Untuk itu penggunaan dukungan teknologi menjadi alternatif untuk diterapkan dengan tidak mengabaikan pula kaedah konservasi dan sosial.

Rekayasa alat serbaguna dari prototipe Expo-2000 yang telah dicoba dalam beberapa tahun ini memperlihatkan bahwa penggunaannya cukup produktif, efektif dan efisien. Hasil analisis data produktivitas kerja sebesar rata-rata $5 \mathrm{~m}^{3} \cdot \mathrm{hm} / \mathrm{jam}$ dan biaya pengeluarannya sebesar Rp 12.035 per $\mathrm{m}^{3}$ cukup jelas memberikan harapan penggunaan alat yang lebih praktis dan ekonomis. Hasil telaahan tingkat efisiensi itu akan menjadi 3-6 kali lebih murah dibanding cara manual. Sementara dampak terhadap lingkungannya juga rendah atau dapat diabaikan. 


\section{KESIMPULAN}

1. Expo-2000 merupakan alat serbaguna yang dapat dipakai untuk pengumpulan kayu dengan cara (1) disarad (2) sistem endless maupun sistem menggantung (sky line) serta untuk kegiatan muat bongkar.

2. Hasil uji coba memberikan gambaran produktivitas pengumpulan 5-6 $\mathrm{m}^{3} \cdot \mathrm{hm} / \mathrm{jam}$ dan muat $53 \mathrm{~m}^{3} \cdot \mathrm{m} / \mathrm{jam}$ dan bongkar $56 \mathrm{~m}^{3} \cdot \mathrm{m} / \mathrm{jam}$.

3. Penggunaan bahan bakar adalah kurang lebih 1 liter per jam kerja mesin.

4. Dengan harga alat diperhitungkan seharga Rp 100 juta (termasuk kabel dan kelengkapan lainnya), biaya operasinya adalah sebesar Rp 60.175 per jam, atau Rp 12.035 per m³ $^{3} . \mathrm{m}$. Sedang biaya pemuatan $\mathrm{Rp} 1.135$ per $\mathrm{m}^{3} . \mathrm{m}$. Biaya ini tentu masih dapat dikatakan cukup murah dibanding cara manual yang dapat mencapai Rp 35.000 atau bahkan lebih tergantung kondisi lapangan dan jarak.

5. Beberapa perbaikan masih perlu dilakukan antara lain model carriage dan sistem pengangkutan alat.

\section{DAFTAR PUSTAKA}

Anonim. 1974. Logging and log transportation in tropical high forest. FAO Forestry Development Daper No. 18. FAO. Rome.

Dulsalam dan A. Suzanto, 1997. Efisiensi pengangkutan dan muat bongkar kayu di suatu pengusahaan hutan di Kalimantan Tengah. Bulletin Penelitian Hasil Hutan 15 (1):

7 17. Pusat Penelitian dan Pengembangan Hasil Hutan. Bogor.

2000. Penelitian perbaikan praktek pemanenan hutan tanaman industri (HTI) di PT.Inhutani II Pulau Laut. Kerjasama Penelitian PT Inhutani II dengan Pusat Penelitian Hasil Hutan. Pusat Penelitian Hasil Hutan. Bogor.

Endom, Wesman dan Z. Basari. 2001. Produktivitas kerja dan biaya alat serbaguna Exp-2000. Naskah publikasi. Pusat Penelitian dan Pengembangan Teknologi Hasil hutan Tidak diterbitkan.

S. Tohdjaya dan Y Sugilar. 2003. Peningkatan produktivitas kerja alat muatsarad serbaguna Exp-2000 hasil perbaikan. Buletin Penelitian Hasil Hutan 21 (3) : 277 289. Pusat Penelitian dan Pengembangan Teknologi Hasil Hutan. Bogor.

Rochmadi dan Soenarso, S. 1976. Pemungutan kayu (logging plan) hutan Pinus merkusii bahan baku pabrik kertas Notog, Jawa Tengah. Perum Perhutani. Jakarta.

Sutton, A dan T.R. Sawyer. 1971. Loading and Unloading Timber Lorries. Forest Commission Forest Record. Her Mayesty Stationenery Office. London WC1 V6HP, 53 pp.

Tinambunan, D. 1982. Alat pemuat kayu bulat ke atas truk, Jaban type I. Leaflet Pusat Penelitian dan Pengembangan Hasil Hutan. Bogor.

Wasono, P. 1965. Prestasi kerja pekerjaan bidang kehutanan. Laporan Lembaga Penelitian Hasil Hutan. Bogor. 